\title{
Prospective model of the hybrid shunting diesel locomotive
}

\author{
Serhii Buriakovskyi ${ }^{1}$, Artem Maslii ${ }^{2}$, Daniil Pomazan ${ }^{2}$, and Olga Pasko ${ }^{3 *}$ \\ ${ }^{1}$ SRDI «Molniya» of the NTU «Kharkov Polytechnic Institute», Kyrpychova str., 2, 61002, Kharkiv, Ukraine; \\ ${ }^{2}$ Ukrainian State University of Railway Transport, Department of electroenergy, electrical equipment and electromecanics, \\ Feierbakh sq., 7, 61050 Kharkiv, Ukraine; \\ ${ }^{3}$ Ukrainian State University of Railway Transport, Department of rolling stock operation and repair, Feierbakh sq., 7, 61050 \\ Kharkiv, Ukraine
}

\begin{abstract}
In the article, the studies are performed which confirm dependence of fuel consumption of the shunting locomotive on the train driving mode. Using a hybrid power plant in the shunting diesel locomotive is proposed, which can help significantly reduce fuel consumption, since shunting will mostly be powered by an alternative power source, and provide high environmental cleanliness of the locomotive both with the basic DC motor and the proposed new traction motor type - switched reluctance motor.
\end{abstract}

\section{Introduction}

Global trends in transport development show an ecological priority combined with energy efficiency. A particular attention in this matter is given to land transport. As rail transport is energy-intensive, highly demanded and widely used in all developed countries, the relevance of applying advanced technologies in this field is of the utmost importance. The specific operating mode is shunting operation, when the use of electric locomotives is almost impossible and the operating modes differ from the magistral ones. The proposed paper is devoted to the study of these specific problems.

\section{Methodology}

Figure 1 shows a functional diagram of the hybrid diesel locomotive, which includes diesel D, synchronous generator SG, (diesel-generator set D-GS), rectifier R, energy storage (battery pack $\mathrm{BP}$, capacitor battery $\mathrm{CB}$, supercondensers), static converter $\mathrm{SC}$ and traction motor TM $[1,2]$.

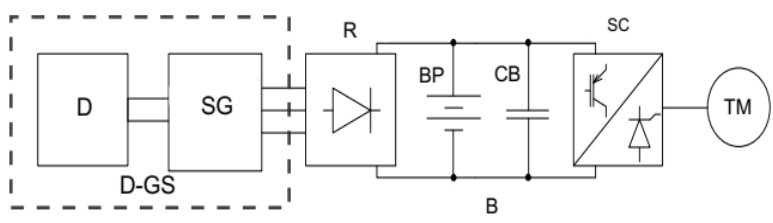

Fig. 1. Functional diagram of the hybrid diesel locomotive.
Using this solution, fuel consumption can be significantly reduced, since shunting will mostly be powered by a traction battery and high environmental cleanliness of the locomotive can be provided.

Since the significant amount of shunting is performed with the ChME3 locomotive, it is advisable to use it as a basis for conducting further studies. The following parameters of the design elements are taken for simulation: K6S310DR diesel, TD-802 DC generator, TE-006 DC traction motor (DCM). The simulation model was used as a tool to obtain the basic oscillograph chart of the locomotive operation.

Specialists of the Ukrainian State University of Railway Transport (Kharkiv) have proposed a mathematical model of the diesel locomotive CHME3, which allows displaying the operation of the locomotive in the real track section with simulation of train driving by the engine driver.

In the study of the train operation using a simulation model, tachograms were set with maximum speeds in the range of $40-70 \mathrm{~km} / \mathrm{h}$ in $10 \mathrm{~km} / \mathrm{h}$ increments. Figures 2 and 3 show examples of oscillograph charts of a shunting locomotive with 10 cars during movement, where: 1 given tachogram; 2 - actual speed of the train; 3 - track profile; 4 - fuel consumption; 5 - number of the engine driver's controller position; 6 - traction motor voltage; 7 - traction motor current. 

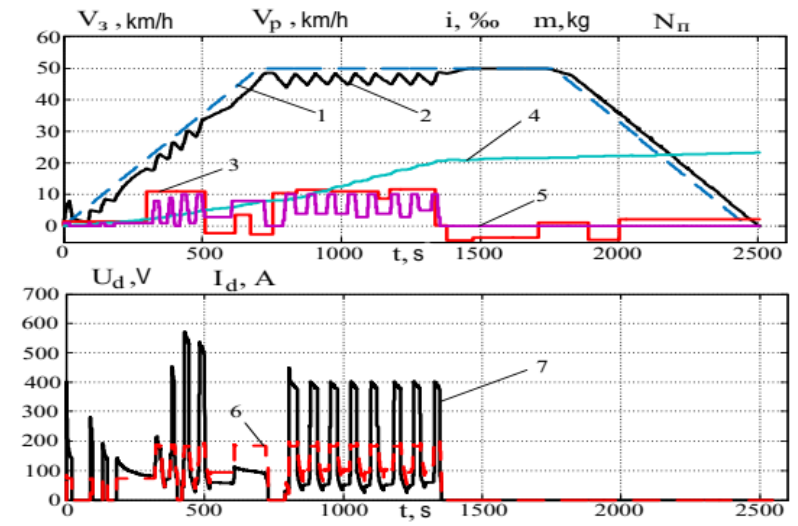

Fig. 2. Oscillograph charts of locomotive operation at maximum speed $50 \mathrm{~km} / \mathrm{h}$.
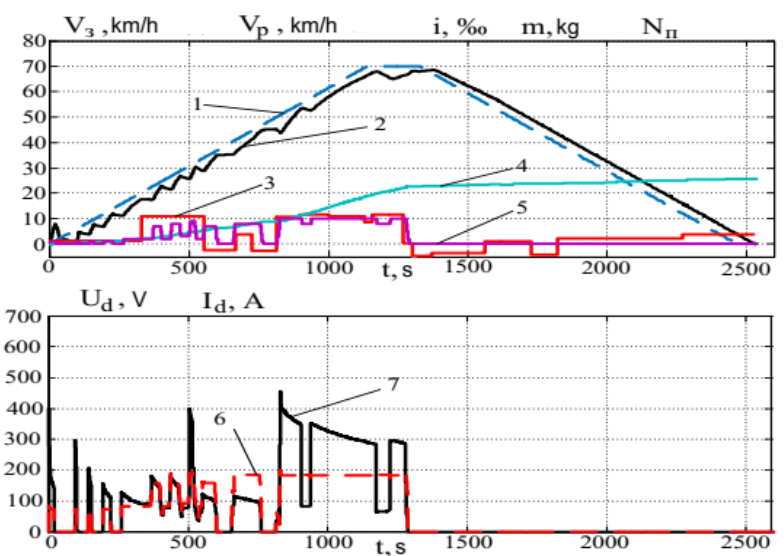

Fig. 3. Oscillograph charts of locomotive operation at maximum speed $70 \mathrm{~km} / \mathrm{h}$.

In the obtained oscillograph charts, curve 5 shows the set of positions which changes with different values of maximum speed. Each position corresponds to a change in the voltage and the current rate in the traction motors, which was limited to $600 \mathrm{~A}$. The diagrams also show that the fuel consumption tends to increase with increase of the maximum speed. By changing the maximum speed of the triangular chart in the range of $70-95 \mathrm{~km} / \mathrm{h}$ in $5 \mathrm{~km} / \mathrm{h}$ increments, the results were obtained which are presented in table form (Table 1) and as a 3D surface (Fig. 4).

Table 1. Results of fuel consumption

\begin{tabular}{|c|c|c|}
\hline $\begin{array}{c}\text { Maximum speed of a } \\
\text { triangular tachogram, } \\
\mathrm{km} / \mathrm{h}\end{array}$ & $\begin{array}{c}\text { Maximum train speed } \\
\text { according to } \\
\text { tachogram, } \mathrm{km} / \mathrm{h}\end{array}$ & $\begin{array}{c}\text { Fuel } \\
\text { consumpti } \\
\text { on, } \mathrm{kg}\end{array}$ \\
\hline \multirow{2}{*}{70} & 40 & 30.07 \\
\cline { 2 - 3 } & 50 & 30.96 \\
\cline { 2 - 3 } & 60 & 31.38 \\
\cline { 2 - 3 } & 70 & 31.14 \\
\hline \multirow{3}{*}{75} & 40 & 30.05 \\
\cline { 2 - 3 } & 50 & 30.82 \\
\cline { 2 - 3 } & 60 & 31.69 \\
\hline
\end{tabular}

\begin{tabular}{|c|c|c|}
\hline & 70 & 30.6 \\
\hline \multirow{4}{*}{80} & 40 & 30.06 \\
\hline & 50 & 30.79 \\
\hline & 60 & 31.61 \\
\hline & 70 & 31.87 \\
\hline \multirow{4}{*}{85} & 40 & 31.33 \\
\hline & 50 & 30.35 \\
\hline & 60 & 32.64 \\
\hline & 70 & 33.18 \\
\hline \multirow{3}{*}{90} & 50 & 30.84 \\
\hline & 60 & 34.04 \\
\hline & 70 & 34.02 \\
\hline \multirow{3}{*}{95} & 50 & 32.59 \\
\hline & 60 & 34.4 \\
\hline & 70 & 35.72 \\
\hline
\end{tabular}

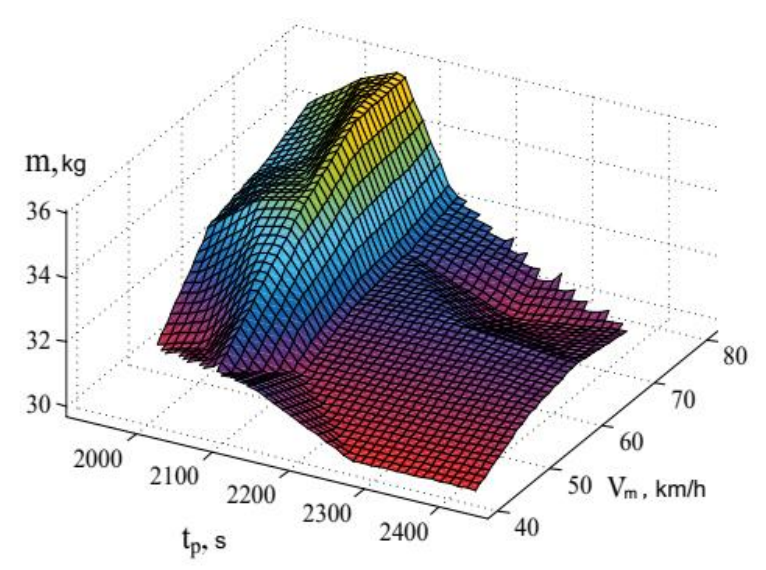

Fig. 4. Change of fuel consumption depending on the maximum speed and the time of movement in the track section.

The obtained surface confirms the dependence of the fuel consumption of the locomotive on the train driving mode (on the time of operation of the locomotive at a certain position and the intensity of the transition from one position to another) when performing the same work, i.e. the same time of movement in the track section. The lowest fuel consumption, namely $29-31 \mathrm{~kg}$, was recorded when the maximum speed was $40-50 \mathrm{~km} / \mathrm{h}$.

In the next stage, studies were conducted to consider the possibility of using a hybrid power plant on a shunting locomotive both with basic DCM, and with a switched reluctance motor (SRM).

A generalized functional diagram of a hybrid diesel locomotive is shown in Figure 5. 


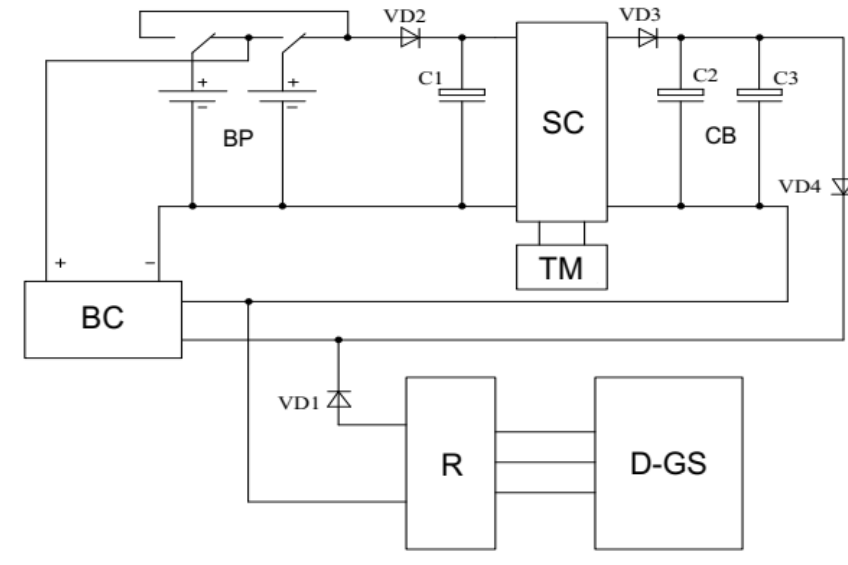

Fig. 5. Generalized functional diagram of the hybrid diesel locomotive.

The diagram above includes also a battery charger (BC) which is not shown in Figure 1.

Using the general functional diagram and the functional diagrams of the individual blocks, a simulation model of operation of the hybrid locomotive was developed in the Matlab environment, where a traction DSM was used with a control system based on the pulsewidth converter (PWC). The proposed model was developed taking into account the possibility of switching traction motors to the generator (regenerative) mode in order to accumulate energy on the supercondensers. Regenerative braking was used up to a speed of $10 \mathrm{~km} / \mathrm{h}$ with the consequent use of pneumatic brakes $[3,4,5]$.

In the study of the operation of a hybrid locomotive using a simulation model, tachograms were set with the maximum speeds in the range of $40-80 \mathrm{~km} / \mathrm{h}$ in $10 \mathrm{~km} / \mathrm{h}$ increments. Figures 6 and 7 show examples of oscillograph charts of a shunting locomotive with 10 cars during movement, where: 1 - given tachogram; 2 - actual speed of the train; 3 - track profile; 4 - fuel consumption; 5 - number of the engine driver's controller position; 6 traction motor current; 7 - capacitor current; 8 - battery pack current.

To maintain the current speed according to a given tachogram, the engine driver changed the voltage on the traction motors by changing the position of the engine driver's controller $[5,6,7,8]$. A change of one position corresponds to a $10 \%$ change in the output voltage level of the pulse-width converter. In the traction mode, current was limited to $600 \mathrm{~A}$. The negative current values on the curve correspond to the recovery mode and the capacitor charge. When the voltage of the supercondenser reached $300 \mathrm{~V}$, charging of the battery pack (BP) began. In order to study the dependence of changing fuel consumption on changing the train driving mode train, fix fuel consumption should be recorded.

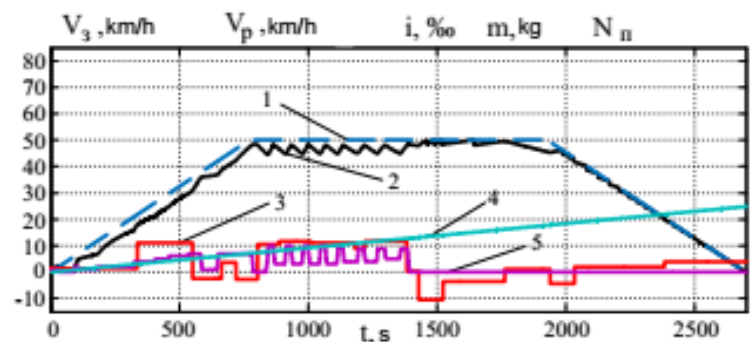

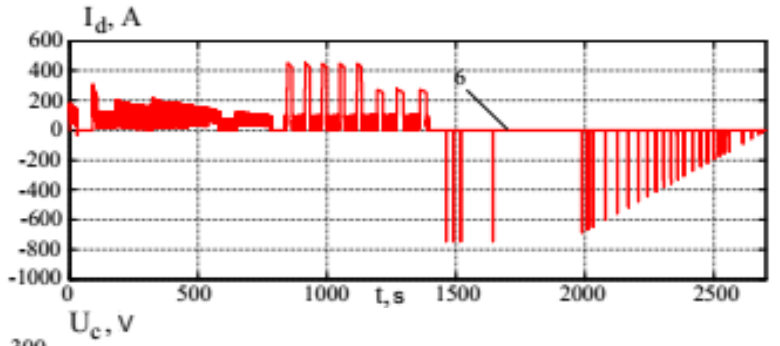
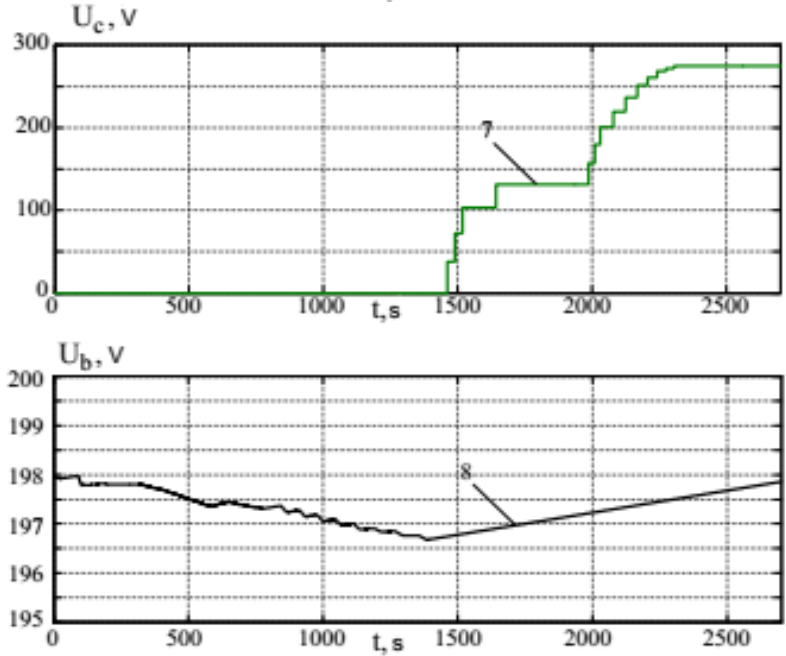

Fig. 6. Oscillograph charts of locomotive operation with DSM at maximum speed $50 \mathrm{~km} / \mathrm{h}$.
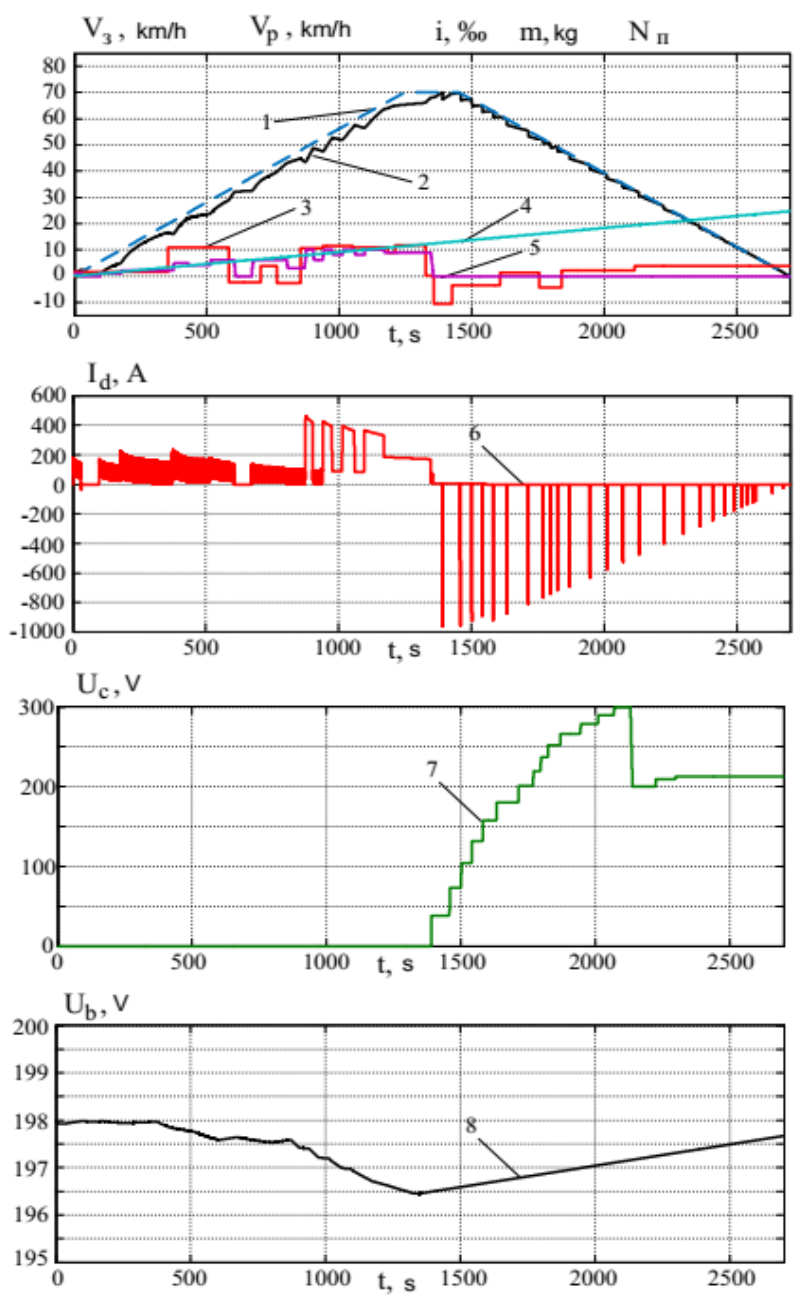

Fig. 7. Oscillograph charts of locomotive operation with DSM at maximum speed $70 \mathrm{~km} / \mathrm{h}$. 
Table 2. Simulation results

\begin{tabular}{|c|c|c|c|c|}
\hline $\begin{array}{c}\text { Maximum } \\
\text { speed of a } \\
\text { triangular } \\
\text { tachogram, } \\
\mathrm{km} / \mathrm{h}\end{array}$ & $\begin{array}{c}\text { Maximum } \\
\text { train speed } \\
\text { according } \\
\text { to } \\
\text { tachogram, } \\
\mathrm{km} / \mathrm{h}\end{array}$ & $\begin{array}{c}\text { Fuel } \\
\text { consumption, } \\
\mathrm{kg}\end{array}$ & $\begin{array}{c}\text { BP } \\
\text { voltage, } \\
\text { V }\end{array}$ & $\begin{array}{c}\text { CB } \\
\text { voltage } \\
\text { V }\end{array}$ \\
\hline \multirow{4}{*}{70} & 40 & 24.48 & 198 & 273 \\
\hline & 50 & 24.41 & 197.9 & 283 \\
\hline & 60 & 24.24 & 197.6 & 234 \\
\hline & 70 & 24.39 & 197.5 & 213 \\
\hline \multirow{4}{*}{75} & 40 & 24.43 & 198 & 277 \\
\hline & 50 & 24.46 & 197.9 & 279 \\
\hline & 60 & 24.37 & 197.7 & 228 \\
\hline & 70 & 24.38 & 197.6 & 208 \\
\hline \multirow{4}{*}{80} & 40 & 24.58 & 198 & 271 \\
\hline & 50 & 24.53 & 197.8 & 274 \\
\hline & 60 & 24.47 & 197.6 & 221 \\
\hline & 70 & 24.32 & 197.6 & 210 \\
\hline \multirow{4}{*}{85} & 43 & 24.98 & 197.9 & 278 \\
\hline & 50 & 25.27 & 197.6 & 284 \\
\hline & 60 & 24.68 & 197.8 & 241 \\
\hline & 70 & 24.73 & 197.7 & 253 \\
\hline \multirow{3}{*}{90} & 50 & 25.09 & 197.3 & 292 \\
\hline & 60 & 24.82 & 197.4 & 240 \\
\hline & 70 & 24.67 & 197.2 & 261 \\
\hline \multirow{3}{*}{95} & 50 & 24.64 & 197.1 & 298 \\
\hline & 60 & 24.59 & 197.2 & 235 \\
\hline & 70 & 24.37 & 197 & 242 \\
\hline
\end{tabular}

Using the data of Table 2, dependences were plotted in form of 3D surfaces: fuel consumption (Fig. 8), BP voltage (Fig. 9), capacitor battery (CB) voltage (Fig. 10) on the maximum speed of the tachogram and time of movement in the track section.

The obtained dependence of fuel consumption suggests that a diesel locomotive with a hybrid power plant is more energy efficient than the traditional one [9, $10,11,12]$. There are two evident maximums at $80 \mathrm{~km} / \mathrm{h}$ and $50 \mathrm{~km} / \mathrm{h}$ for the triangular chart with a maximum speed of $90 \mathrm{~km} / \mathrm{h}$. These extreme values are 25.11 and $25.09 \mathrm{~kg}$, respectively. The reduction in fuel consumption of the locomotive is in the range of $5.62-11.2 \mathrm{~kg}$ compared to the traditional system (Table 1), which is $18.7 \%$ to $31.3 \%$.

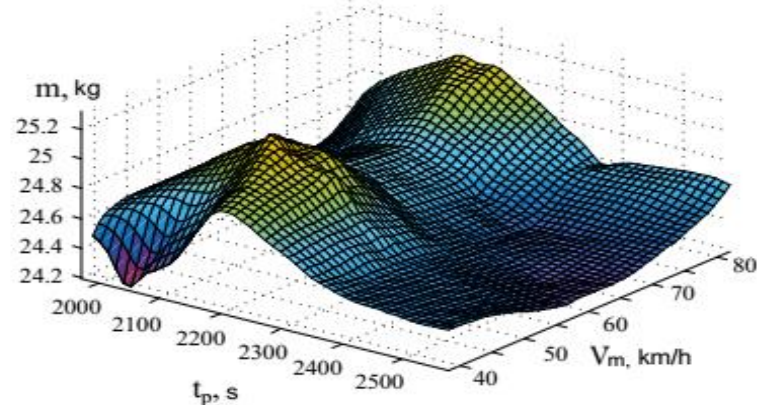

Fig. 8. Change of fuel consumption by a hybrid locomotive depending on the maximum speed and time of movement in the track section.

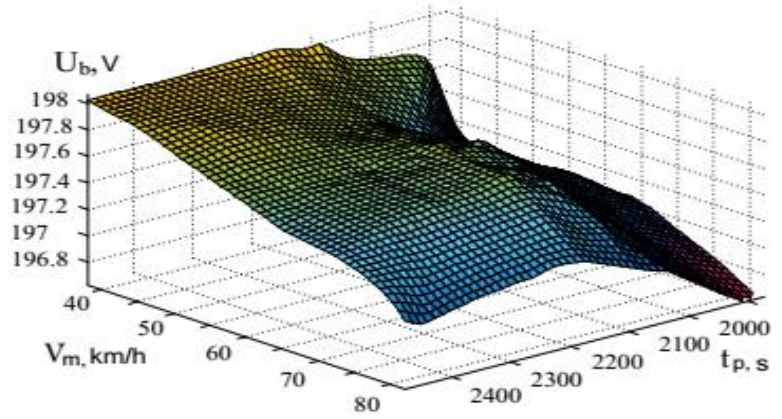

Fig. 9. Change of BP voltage depending on the maximum speed and time of movement in the track section.

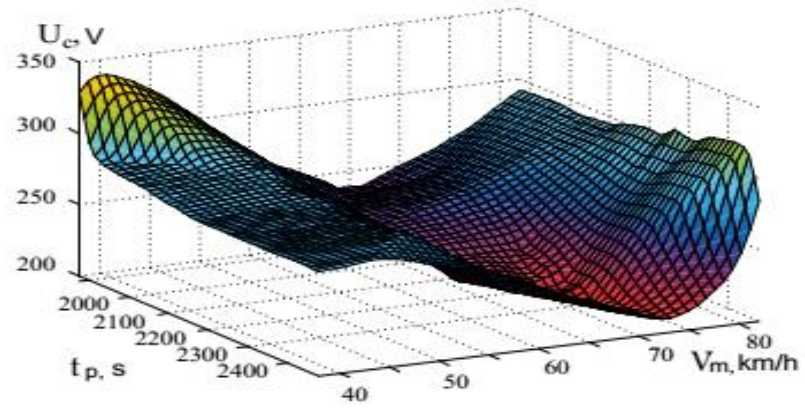

Fig. 10. Change of BP voltage depending on the maximum speed and time of movement in the track section.

Analysis the dependence of the voltage BP revealed a tendency of the increasing charge of BP when the maximum speeds of movement in the track section reduce.

In the surface (Fig. 10) there is a minimum BP voltage area $(208-261 \mathrm{~V})$ in the speed range $55-75 \mathrm{~km} / \mathrm{h}$, which corresponds to switching to the BP charge mode. In the same speed range, a minimum value area is recorded on the fuel consumption surface as a result of the reduced load on the diesel.

\section{Analysis of the results}

In the next stage, a simulation of the electric drive of the locomotive was performed on the basis of switched reluctance motors (SRM). 


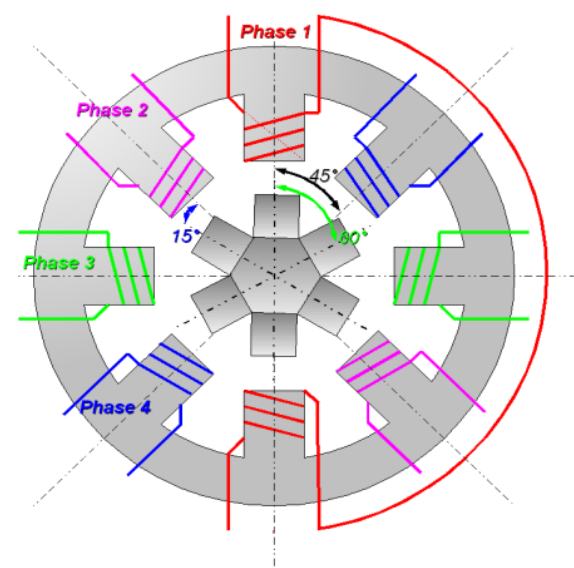

Fig. 11. Four-phase SRM in $8 / 6$ configuration.

Table 3. Technical specification of the motor DVI-165

\begin{tabular}{|c|c|}
\hline \multicolumn{2}{|c|}{ Electrical mechanical parameters } \\
\hline $\mathrm{UH}, \mathrm{V}$ & 200 \\
\hline $\mathrm{IH}, \mathrm{A}$ & 850 \\
\hline $\mathrm{MH}, \mathrm{Nm}$ & 875.5 \\
\hline $\mathrm{n}_{\mathrm{H}}, \mathrm{t} / \mathrm{h}$ & 1800 \\
\hline $\mathrm{R} \phi, \mathrm{Om}$ & 0.135 \\
\hline $\mathrm{Ld}, \mathrm{mGn}$ & 1.72 \\
\hline $\mathrm{Lq}, \mathrm{mGn}$ & 0.36 \\
\hline
\end{tabular}

As a result of the simulation, basic oscillograph charts of locomotive operation were obtained, examples of which are shown in Fig. 12-13, where: 1 - given tachogram; 2 - actual speed of the train; 3 - track profile; 4 - fuel consumption; 5 - number of the engine driver's controller position; 6 - traction motor current; 7 capacitor current; 8 - battery pack current.
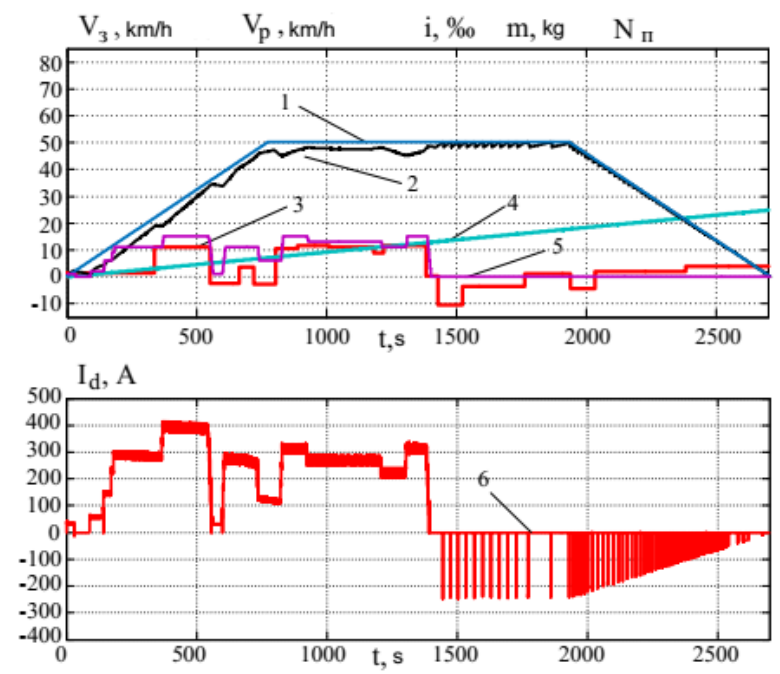
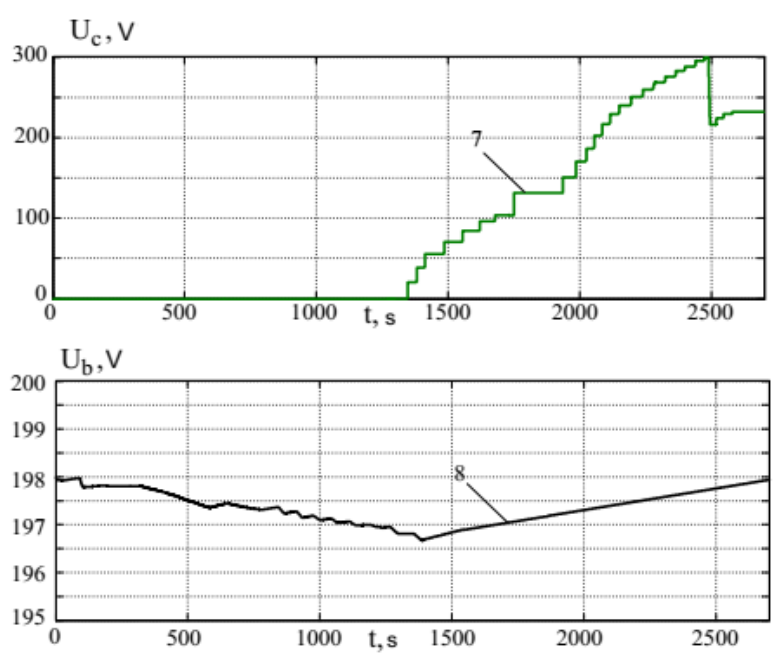

Fig. 12. Oscillograph charts of locomotive operation with SRM at maximum speed $50 \mathrm{~km} / \mathrm{h}$.
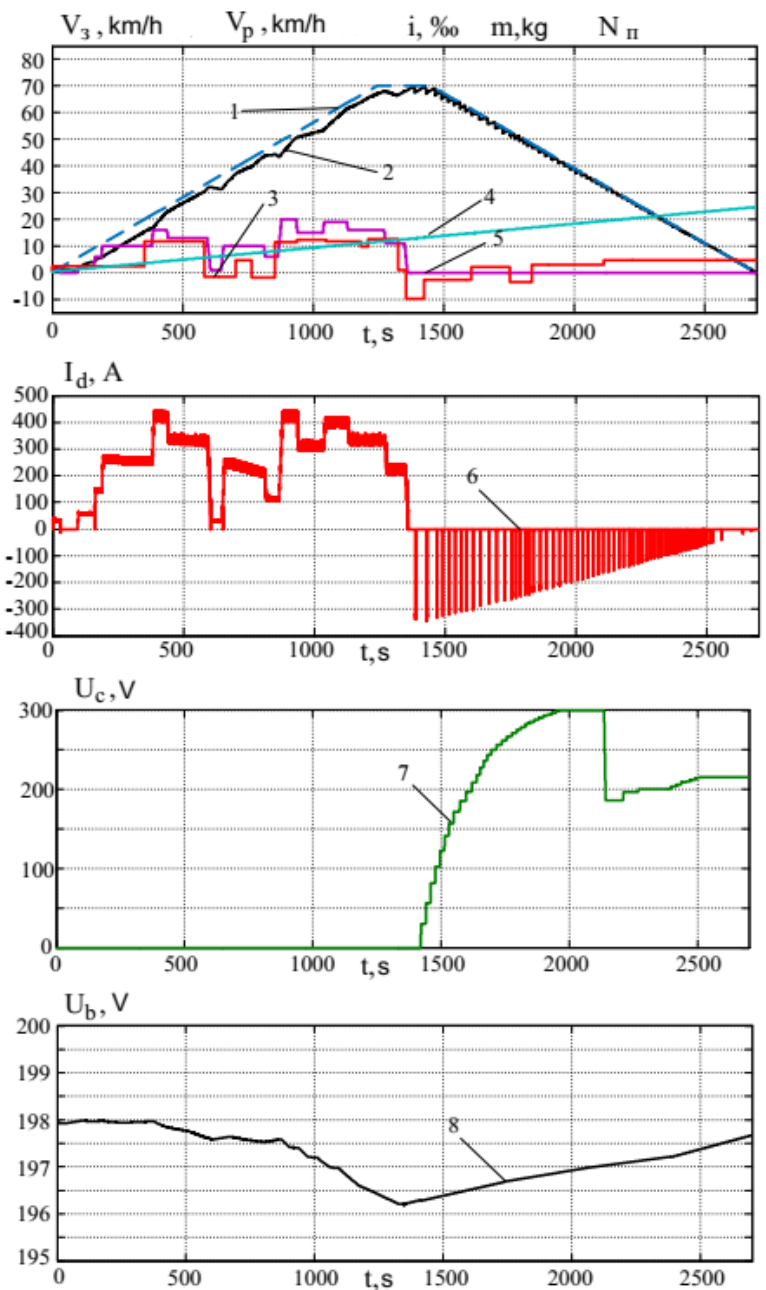

Fig. 13. Oscillograph charts of locomotive operation with SRM at maximum speed $70 \mathrm{~km} / \mathrm{h}$. 
The results of the analysis of the obtained characteristics are summarized in Table 4.

Table 4. Simulation results

\begin{tabular}{|c|c|c|c|c|}
\hline $\begin{array}{l}\text { Maximum } \\
\text { speed of a } \\
\text { triangular } \\
\text { tachog- } \\
\mathrm{ram}, \mathrm{km} / \mathrm{h}\end{array}$ & $\begin{array}{l}\text { Maximum } \\
\text { train } \\
\text { speed } \\
\text { according } \\
\text { to tachog- } \\
\mathrm{ram}, \mathrm{km} / \mathrm{h}\end{array}$ & $\begin{array}{l}\text { Fuel } \\
\text { consum } \\
\text { ption, } \\
\text { kg }\end{array}$ & $\begin{array}{c}\text { BP } \\
\text { voltage, } \\
\text { V }\end{array}$ & $\begin{array}{c}\text { CB } \\
\text { voltag } \\
\text { e, V }\end{array}$ \\
\hline \multirow{4}{*}{70} & 40 & 24.39 & 197.9 & 252 \\
\hline & 50 & 24.41 & 198 & 235 \\
\hline & 60 & 24.24 & 197.5 & 234 \\
\hline & 70 & 24.43 & 197.8 & 292 \\
\hline \multirow{4}{*}{75} & 40 & 24.36 & 197.9 & 251 \\
\hline & 50 & 24.42 & 197.9 & 234 \\
\hline & 60 & 24.37 & 197.6 & 237 \\
\hline & 70 & 24.45 & 197.7 & 294 \\
\hline \multirow{4}{*}{80} & 40 & 24.57 & 197.9 & 250 \\
\hline & 50 & 24.53 & 197.8 & 231 \\
\hline & 60 & 24.47 & 197.7 & 239 \\
\hline & 70 & 24.32 & 197.6 & 215 \\
\hline \multirow{4}{*}{85} & 43 & 24.56 & 197.8 & 254 \\
\hline & 50 & 24.89 & 197.5 & 233 \\
\hline & 60 & 24.43 & 197.9 & 241 \\
\hline & 70 & 24.54 & 197.5 & 221 \\
\hline \multirow{3}{*}{90} & 50 & 24.86 & 197.2 & 263 \\
\hline & 60 & 24.62 & 197.5 & 240 \\
\hline & 70 & 24.47 & 197.3 & 227 \\
\hline \multirow{3}{*}{95} & 50 & 24.41 & 197.2 & 268 \\
\hline & 60 & 24.49 & 197.3 & 235 \\
\hline & 70 & 24.44 & 197.1 & 229 \\
\hline
\end{tabular}

Using the results of Table 4, 3D dependences were plotted in form of surfaces: fuel consumption, BP voltage, $\mathrm{CB}$ voltage on the maximum speed of the tachogram and time of movement in the track section.

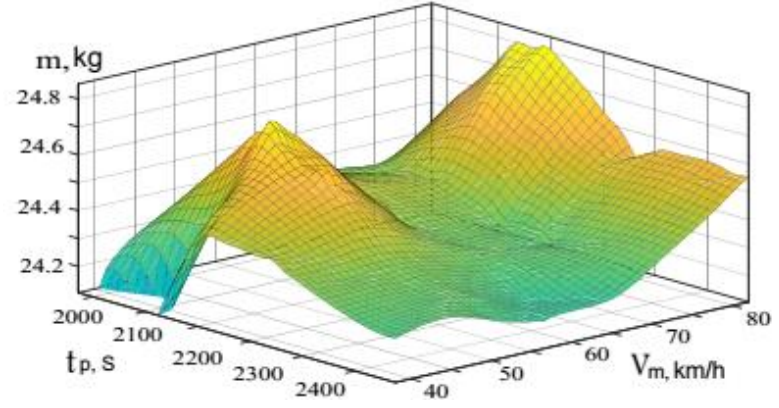

Fig. 14. Change of fuel consumption by a hybrid locomotive with SRM depending on the maximum speed and time of movement in the track section.

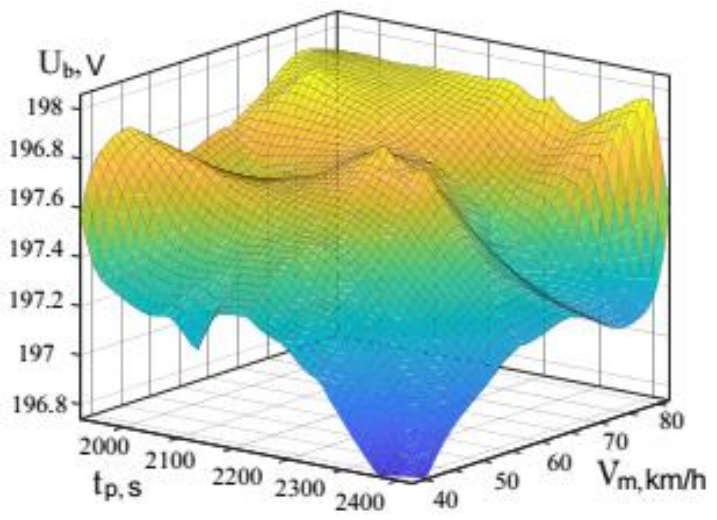

Fig. 15. Change of BP voltage depending on the maximum speed of the triangular chart.

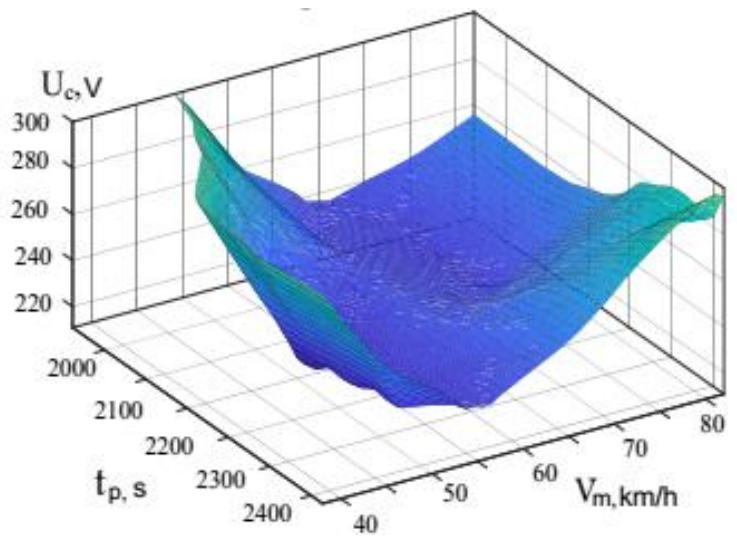

Fig. 16. Change of BP voltage depending on the maximum speed of the triangular chart.

\section{Conclusion}

The analysis of the obtained surfaces shows their similarity to the dependences observed when DSM were used (Fig. 810), but for SRM compared to DSM, the reduction of fuel consumption tended to reduce more intensively as the maximum speeds of the triangular tachograph increased (movement in the line) in the range of $80-95 \mathrm{~km} / \mathrm{h}$. The reduction in fuel consumption in this range is $0.5-1.5 \%$.

Extreme values at speeds of $80 \mathrm{~km} / \mathrm{h}$ and $50 \mathrm{~km} / \mathrm{h}$ with the maximum speed of the triangular chart of $85 \mathrm{~km} / \mathrm{h}$ are 24.92 and $24.89 \mathrm{~kg}$, respectively.

I.e. the above dependences suggest that a diesel locomotive with a hybrid power plant is more energy efficient than the traditional one, and using SRM as a 
traction motor is much more efficient than the existing DSM. However, based on the conducted analysis, the dependence of fuel consumption by the locomotive the train movement mode is determined, so an automatic control system should be developed using a speed controller that would follows the given tachogram more accurately.

\section{References}

1. J.A. Gollandtsev, Electropribor Central Res. Inst. Publ. House, 147 (2003) [in Russian]

2. S. Buriakovskyi, M. Babaiev, B. Liubarskyi, Ar. Maslii, N. Karpenko, D. Pomazan, An. Maslii, I. Denis, Eastern-Europ. Journ. of Enterprise Techn., 1/2 (91), 68-75, (2018)

3. S.G. Burjakovskyi, A.S. Maslii et. al. Electronics and electromechanics, 2, 59-62 (2018) [in Ukrainian]

4. Ar. Masliy, D. Pomazan, 2019 IEEE International Conference on Modern Electrical and Energy Systems (MEES), 22-25 (2019)

5. B. Lyubarskiy, Ar. Masliy, An. Maslii, D. Pomazan, V. Panchenko, $9^{\text {th }}$ International Conference Advanced computer information technologies ACIT'2019, 76-79 (2019)

6. R. Krishnan, Modeling. Simulation, Analysis, Design and Applications, CRC Press, 398 (2001)

7. An.S. Maslii, S.G. Buriakovskyi, Ar.S. Maslii, B.G. Lyubarskij, UkrDASZT, 5 (102), 68-74 (2013) [in Ukrainian]

8. R. Krishnan, Modeling. Simulation, Analysis, Design and Applications, CRC Press, 324 (2006)

9. M.Cipek, D. Pavkovic, Z. Kljaic, T. Mlinaric, Energy [online], 173, 1154-1171 (2019)

10. V. Bapiraju, Y.B.S. Phanindra, Int. Journ. for Research in Appl. Science and Eng. Techn. [online], 6(VI), 1699-1705 (2018)

11. Q. Xin, Diesel Engine System Design, 348-394 (2013)

12. V. Franzitta, D. Curto, D. Milone, M. Trapanese, Sustainability, 9 (12), 106 (2017) 